\title{
SPATIAL PATTERNS OF BREAST CANCER MORBIDITY (THE CASE OF CHERNIHIV REGION)
}

\author{
'Tetiana SHOVKUN, ${ }^{2}$ Vasyl KOSTIUK \\ 'Gogol Nizhyn State University, Ukraine \\ ${ }^{2}$ Chernihiv Regional Oncology Centre, Ukraine \\ 'tmshov@ukr.net
}

\begin{abstract}
The paper analyzes breast cancer morbidity in the female population of Chernihiv region. The research of current trends in morbidity and mortality of the female population due to breast cancer was conducted in several stages. The first stage provided for the collection of statistical information, the second stage involved the analysis of quantitative indicators. The analysis of the current epidemiological situation was conducted using a personalized database of the National Cancer Registry of Ukraine and indicators of health status, activities and resources for municipal health care institutions in Chernihiv region using the gross rates of morbidity and mortality. The final stage of the study was to determine the level of public health in view of breast cancer and investigation of its territorial differences within Chernihiv region. It was found out that the period of 2000 2015 was characterized by a clear trend of increasing morbidity and stabilizing mortality due to breast cancer both within the region and the country. However, the rate of breast cancer morbidity in female population in Chernihiv region is lower than in Ukraine. Stabilization of breast cancer mortality is associated with early cancer diagnostics, as well as introduction of new technologies for diagnosis and treatment of cancer.
\end{abstract}

Key words: health condition, female population, morbidity, mortality, age peculiarities.

DOI: https://doi.org/10.17721/2413-7154/2017.77.71-77

UDC: 911.3

\section{ТЕРИТОРІАЛЬНІ ОСОБЛИВОСТІ ЗАХВОРЮВАНОСТІ НА РАК МОЛОЧНИХ ЗАЛОЗ (НА ПРИКЛАДІ ЧЕРНІГІВСЬКОЇ ОБЛАСТІ)}

\author{
'Тетяна ШОВКУН, ${ }^{2}$ Василь КОстюК \\ ${ }^{1}$ Ніжинський державний університет імені Миколи Гоголя, Україна \\ гчернігівський обласний онкологічний диспансер, Україна \\ 'tmshov@ukr.net
}

\begin{abstract}
Анотація: У статті проаналізовано стан захворюваності жіночого населення Чернігівської області на рак молочних залоз. Дослідження сучасних тенденцій стану захворюваності та смертності жіночого населення від раку молочних залоз було проведено в кілька етапів. Перший етап включав в себе збір статистичної інформації, другий етап - аналіз кількісних показників. Аналіз сучасного стану епідеміологічної ситуації захворювання на рак молочних залоз був проведений на основі персоніфікованої бази даних Національного канцер-реєстру України та показників стану здоров'я населення, діяльності та ресурсного забезпечення комунальних закладів охорони здоров'я Чернігівської області з використанням грубого показника захворюваності та смертності. Завершальним етапом дослідження стало визначення рівня соціальної напруженості і встановлення її територіальних відмінностей в межах Чернігівської області. Проведено порівняння стану захворюваності та смертності жіночого населення від раку молочних залоз в Чернігівській області та в Україні, а також здійснено групування адміністративних районів Чернігівської області за рівнем соціальної напруженості відповідно до показників стану здоров'я жіночого населення, що пов'язані з раком молочних залоз. Виявлено, що за період 2000-2015 років спостерігається чітка тенденція до збільшення показника захворюваності та стабілізація показника смертності від раку молочних залоз як в межах області, так і у межах країни. Показник захворюваності жіночого населення на рак молочних залоз у Чернігівській області $\epsilon$ меншим, ніж в Україні. Стабілізація показника смертності пов'язана із виявленням раку молочних залоз на ранніх стадіях, а також впровадженням новітніх технологій діагностики і лікування злоякісних новоутворень.
\end{abstract}

Ключові слова: стан здоров'я, жіноче населення, захворюваність, смертність, вікові особливості, територіальна структура.

DOI: https://doi.org/10.17721/2413-7154/2017.77.71-77

UDC: 911.3

Постановка проблеми. Серед багатьох складних проблем, які сьогодні переживає Україна, найбільше занепокоєння викликає стан здоров'я населення. Аналізуючи основні тенденції стану здоров'я населення України за останні роки, можна

(C) Т. Шовкун, В. Костюк

чітко простежити погіршання його стану. Злоякісні новоутворення разом із серцево-судинними хворобами $\epsilon$ одними 3 домінуючих у структурі захворюваності населення. Для них характерною $\epsilon$ складність своєчасної діагностики, висока вартість і важкість лікування та значний рівень інвалідизації. 
Аналіз вікової структури захворюваності на злоякісні новоутворення для жіночого населення вказує на те, що найбільш вразливим є працездатний вік: 30-54 р. - 25,2\%, 55-64 р. - 26,0\%. Цей факт посилює соціально-економічну значимість проблеми боротьби із цим захворюванням. Перше місце серед злоякісних новоутворень усіх локалізацій у структурі захворюваності жіночого населення займає рак молочних залоз. В Україні, як і в Чернігівській області, відмічається збільшення показника захворюваності раку молочних залоз. Соціально-економічна значимість проблеми також полягає в тому, що питома вага у структурі смертності від раку молочної залози серед жінок склала у 2015 році 20,1\%. У віці 30-54 роки, що є найбільш працездатним, показник смертності складає 18,1\% [2].

Аналіз останніх досліджень і публікацій. Здоров'я населення є не лише об'єктом системи охорони здоров'я, а являє собою i соціальнодемографічну характеристику. Питанню вивчення стану здоров'я жіночого населення, а також територіальним особливостям поширення захворюваності раку молочної залози присвячені праці як медиків так і географів Серед медиків особливості епідеміології та алгоритм лікування раку молочної залози висвітлені у працях Туз Є.В., Романчук В.Р., Пономарєвої О.В., Пивнюк В.М., Горбатюк Т.А., Осинського Д.С. та інших. Дослідженням впливу навколишнього середовища на виникнення раку молочних залоз займалися Пятчаніна Т.В., Огороднік А.М. Територіальні особливості захворюваності раку молочних залоз у Закарпатській області викладені у досліджені Русин А.В. та Русин I.В., у ІваноФранківській області - Анурів А.В., Романчук В.Р., Крижанівської А.С. Серед географів дослідження впливу навколишнього природного середовища на здоров'я населення та територіальний розподіл захворюваності хвороб різних класів вивчали Л. Нємець, А. Корнус, О. Корнус, В. Шищук .

Метою нашого дослідження $€$ виявлення соціальної напруженості від раку молочних залоз та встановлення іiі територіальних відмінностей у межах Чернігівської області. Основні завдання дослідження:

- проаналізувати особливості захворюваності жіночого населення на рак молочних залоз;

- встановити сучасні тенденції смертності жіночого населення від раку молочних залоз;

- виявити територіальні відмінності соціальної напруженості від раку молочних залоз у межах Чернігівської області.

Опис методики дослідження. Дослідження сучасних тенденцій стану захворюваності та смертності жіночого населення від раку молочних залоз було проведено в кілька етапів. Перший етап включав в себе збір статистичної інформації, другий етап - аналіз кількісних показників. Завершальним етапом дослідження стало визначення рівня соціальної напруженості і встановлення ii територіальних відмінностей в межах Чернігівської області. Аналіз сучасного стану епідеміологічної ситуації захворювання на рак молочних залоз був проведений на основі персоніфікованої бази даних Національного канцер-реєстру України та показників стану здоров'я населення, діяльності та ресурсного забезпечення комунальних закладів охорони здоров'я Чернігівської області 3 використанням грубого показника захворюваності та смертності, оскільки саме грубий показник відображає кількість нових випадків захворювань або смертей, що відбулися в популяції протягом року, віднесені до середньої чисельності цієї популяції в тому самому році, виражені через показник 100 тис. населення, і характеризує частоту захворювань або смертей в регіоні та використовується для аналізу епідеміологічної ситуації в регіоні. Картосхема побудована з використанням ГІС-технологій.

Результати дослідження та обговорення. У 2015 році в Україні було зареєстровано 345,9 випадків захворюваності на злоякісні новоутворення на 100 тис. осіб. У Чернігівській області цей показник $€$ вищим і складав 369,2 випадків на 100 тис. осіб [2]. У структурі захворюваності жінок на першому місці як в Україні в цілому, так і в Чернігівській області зокрема, на першому місці стоїть рак молочної залози. В Україні даний показник складає $19,5 \%$, в області - 18,1\%. На другому місці знаходяться немеланомні злоякісні новоутворення шкіри і складають відповідно 12,8\% та $13,9 \%$. На третьому - злоякісні новоутворення тіла матки, з показниками 9,0\% та 9,8\% [2].

Слід зазначити, що питома вага основних нозологічних форм захворюваності у структурі захворюваності на злоякісні новоутворення серед жіночого населення України за останні десять років суттєвих змін не зазнала. У 2015 році питома вага раку молочної залози (яка є домінуючою у даній структурі) склала 19,5 \% у співвідношенні до 19,9\% у 2010 році. На другому місці залишились немеланомні злоякісні новоутворення шкіри, які склали відповідно у 2015 році $12,8 \%$, а у 2010 році - 13,0\%. На третьому місці - злоякісні новоутворення тіла матки з показниками 9,0\% та 8,5 \% відповідно (Рис. 1).

Натомість чіткою залишається тенденція до збільшення показника захворюваності на рак молочної залози. Рак молочної залози - злоякісне новоутворення, яке здатне до активного метастазування і характеризується активним зростанням.

Виникненню i подальшому розвитку раку молочних залоз сприяють такі фактори:

- гормональні (пряма залежність між розвитком хвороби і рівнем статевих гормонів),

- вік (значне поширення хвороби з 35-річного віку),

- генетичні (підвищення ризику хвороби під впливом спадкового фактора),

- вживання жирів тваринного походження у великих кількостях,

- наявність доброякісних захворювань молочної залози,

- інші фактори (куріння, іонізуюча радіація, хімічні отрути) [6].

Аналіз захворюваності населення на рак молочних залоз дає підстави говорити про те, що збільшення показника захворюваності відбувається хвилеподібно. Але при цьому зберігається чітка 


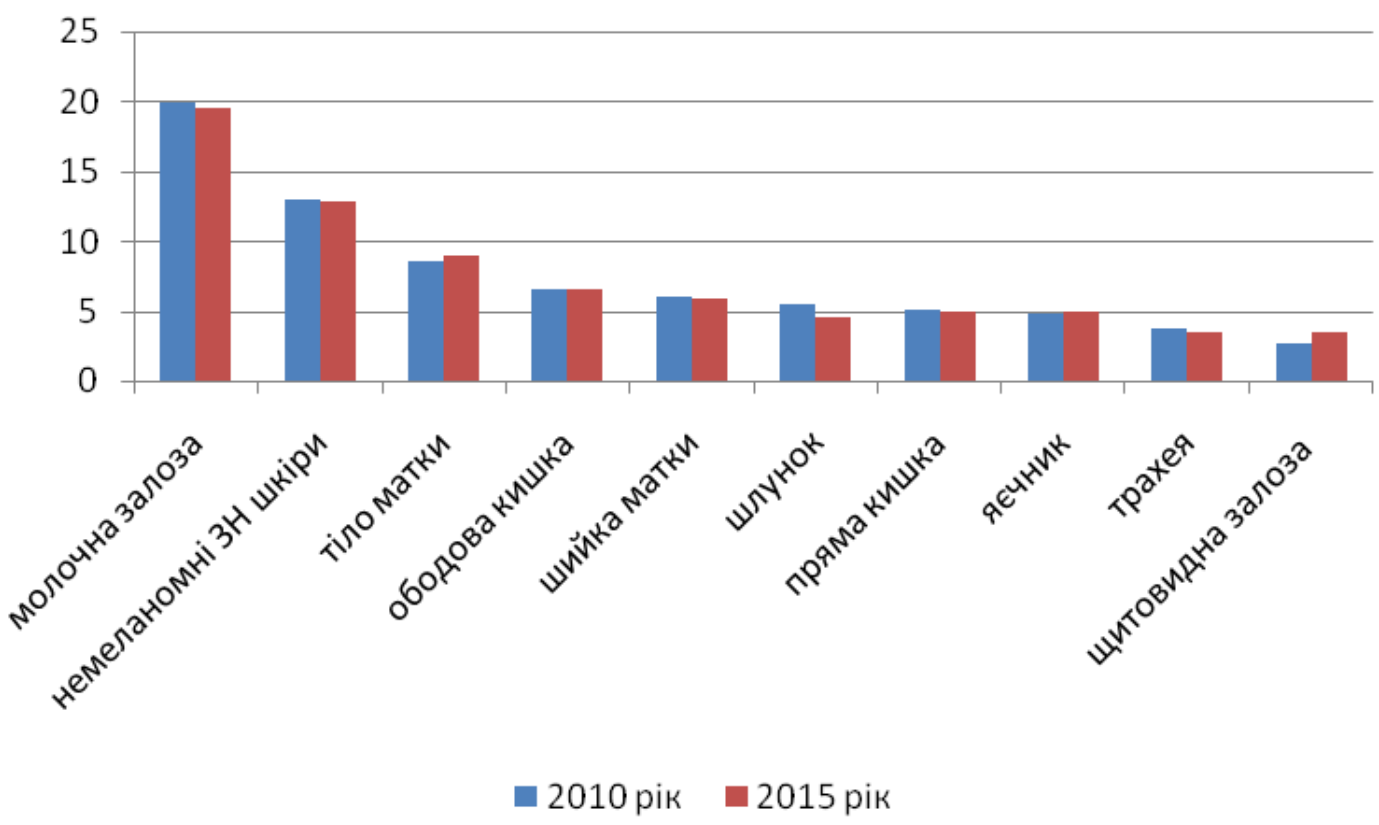

Рис. 1. Питома вага основних нозологічних форм злоякісних новоутворень у структурі захворюваності на злоякісні новоутворення жіночого населення України (складено на основі даних [3])

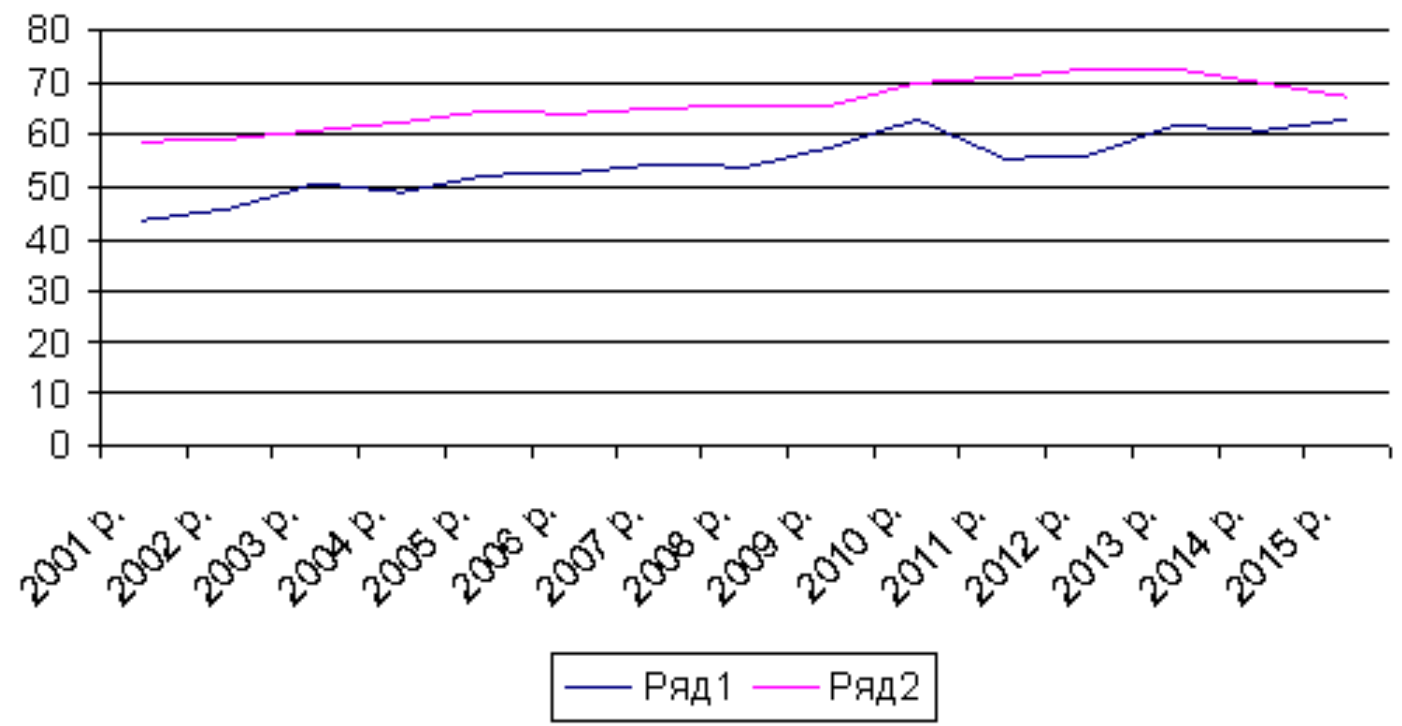

Рис. 2. Динаміка захворюваності жіночого населення на рак молочної залози

(складено на основі даних [3]). Ряд 1 - показники захворюваності на рак молочної залози в Чернігівській області; ряд 2 - показники захворюваності на рак молочної залози в Україні.

тенденція підвищення показника захворюваності як в межах Чернігівської області, так і в Україні в цілому. За останні 15 років в межах Чернігівської області збільшення захворюваності жінок на рак молочної залози відбулося у 1,4 рази, в межах України - в 1,2 рази (Рис. 2).

Серед злоякісних новоутворень захворюваність жіночого населення на рак молочної залози в Україні у 2015 році склала 67,3 випадків, а в Чернігівській області - 62,1 випадків на 100 тис. осіб.

Областями, що мають показники захворюваності значно вищі за середньодержавні є: Миколаївська 79,5, Кіровоградська -78,2, Сумська - 76,8, Черкаська - 76,1, Дніпропетровська - 76,3, Запорізька - 72,2 випадків на 100 тис. жіночого населення. Найменші показники захворюваності характерні для західних територій України: Івано-Франківська область - 45,3, Волинська - 45,7, Закарпатська - 46,1, Чернівецька - 47,0, Рівненська - 47,4 випадків на 100 тис. жіночого населення [3].

Чернігівська область за показником захворюваності на злоякісні новоутворення молочної залози на 100 тис. населення в межах України має показник, що є наближеним до середньоукраїнського. $\mathrm{y}$ той же час в межах області відмічаються територіальні відмінності показника захворюваності. Найбільші показники захворюваності у 2015 році зафіксовані у Варвинському та Чернігівському районах - 99,7 та 91,5 випадків на 100 тис. жіночого населення відповідно. Серед інших районів області, 


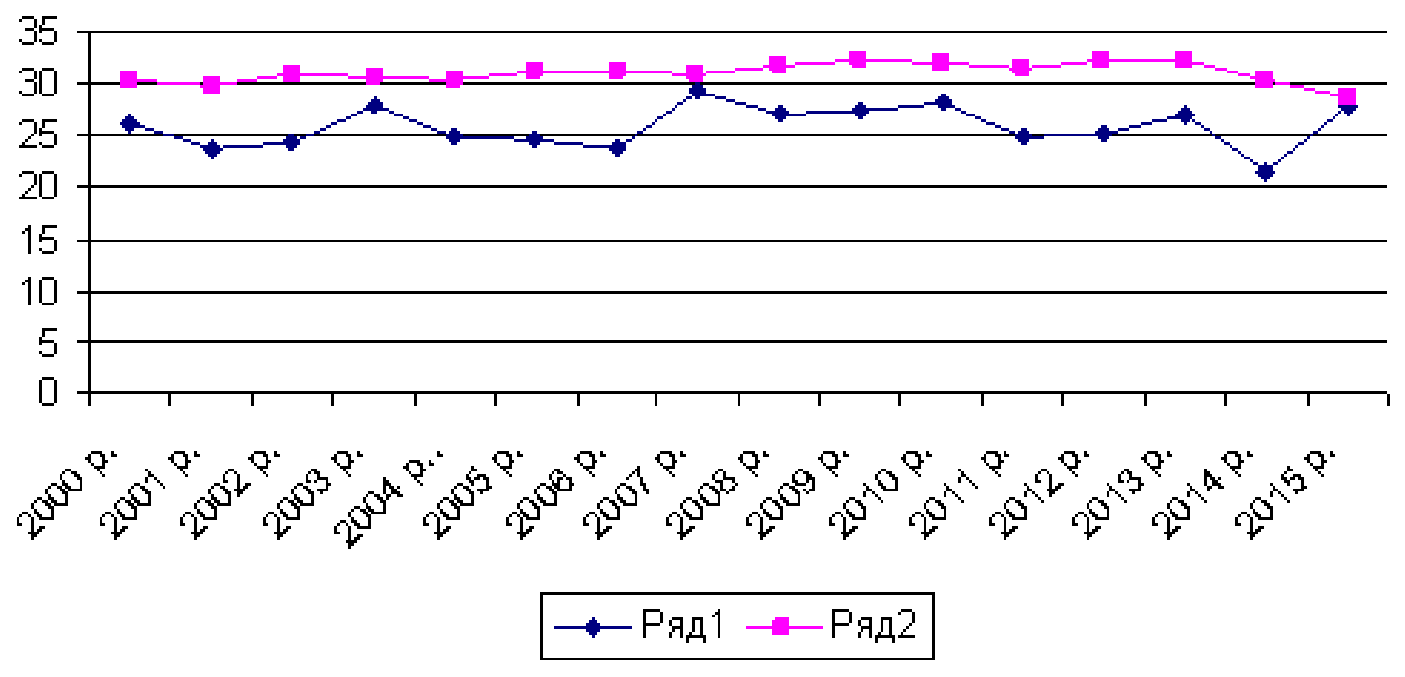

Рис. 3. Динаміка смертності від раку молочної залози (складено на основі даних [3]). Ряд 1 - динаміка смертності в межах Чернігівської області. Ряд 2 - динаміка смертності в межах України.

що мають показники вищі за середньообласні варто відмітити Щорський $(75,6)$, Менський $(74,9)$, Куликівський $(73,6)$ та міста Чернігів $(74,3)$ і Ніжин $(70,4)$. Але в ряді областей зафіксовані показники, що більше ніж у два рази є меншими за середньообласні. У Бахмацькому та Ічнянському районах показник захворюваності склав 28,2, а у Сосницькому - 29,6 випадків на 100 тис. жіночого населення. Найменший показник захворюваності у 2015 році було зафіксовано у Ніжинському районі - 19,1 випадків на 100 тис. осіб.

У дослідженнях проведених В. В. Рудень та Д.Є.Москв'як-Лесняк, що пов'язані 3 аналізом захворюваності жіночого населення на рак молочних залоз в Україні у 2000-2008 роках, встановлена аналогічна тенденція. Вони здійснили групування адміністративних областей України за особливостями поширення захворюваності жінок на рак молочних залоз. Відповідно до даного групування, територія Чернігівської області віднесена до третьої категорії iз п’яти. Найкраща ситуація відмічалася у Західному регіоні [7]. Власне дана тенденція відмічена у дослідження, які були проведені Русин А.В. та Русин I.В з вивчення раку молочних залоз в Закарпатській області. Ними встановлено, що рак молочних залоз у жінок у Закарпатській області зустрічається рідше, ніж в Україні. Крім того, цікавим є дане дослідження в контексті встановлення різниці в захворюваності і смертності міського і сільського населення. Авторами підтверджено, що такі показники є вищими серед міського населення [9].

За показником питомої ваги основних нозологічних форм злоякісних новоутворень у структурі смертності жінок рак молочної залози у жіночого населення уже тривалий період займає перше місце. У 2010 році цей показник склав 20,7\%, у 2015 році - 20,1\%. Крім того, у 2015 році показник смертності від раку молочної залози в межах України склав 28,6 випадків на 100 тис. осіб жіночого населення. Показник смертності вищий за середньоукраїнський відмічався у Запорізькій $(37,5)$, Дніпропетровській $(34,7)$, Полтавській $(32,4), \quad$ Кіровоградській $(31,5)$ областях. Найменші показники смертності зафіксовані в Одеській $(19,2)$, Закарпатській $(20,4)$, Волинській $(21,6)$ областях [3].

Чернігівська область має показник смертності від раку молочної залози наближений до середньоукраїнськогго і він складає 27,1 випадків на 100 тис. осіб жіночого населення. Серед районів Чернігівської області, які мають показник смертності, що майже у 3,5 рази є більшим за середньообласний слід назвати Срібнянський. У 2015 році показник смертності на 100 тис. жіночого населення у межах даного району склав 96,1 випадків, що є у 3,5 рази більшим за середньобласний. У 2,2 рази даний показник є більшим за середньобласний у НовгородСіверському районі і складає 60,6 випадків смертей на 100 тис. жіночого населення. Також високі показники мають Борзнянський $(45,1)$, Сосницький $(39,5)$, Чернігівський $(38,7)$, Щорський $(37,8)$ райони. Найменші показники смертності на 100 тис. жіночого населення в межах області у 2015 р. були зафіксовані у Ніжинському $(6,4)$, Коропському $(7,6)$, Прилуцькому $(10)$, Ічнянському $(11,3)$ Ріпкинському (13),Корюківському $\quad(13,6)$, Талалаївському (14) районах [5].

Але якщо в Чернігівській області зменшення показника смертності фіксується протягом останніх п'яти років, то в межах України така ситуація відмічається лише в останні три роки. Тому, у дослідженнях науковців, які були проведені у попередні роки мова йде про підвищення показника смертності [7,9]. Така нинішня тенденція можлива завдяки впровадженням новітніх технологій діагностики i лікування злоякісних новоутворень, а також виявлення раку молочних залоз на ранніх стадіях.

Виявлення раку молочних залоз на ранніх стадіях захворювання - одне 3 головних завдань лікаря, оскільки перебіг хвороби та виживаність залежать 
від стадії захворювання. При лікуванні раку молочних залоз першої стадії виживаність протягом п'яти років складає 75-90\%, другої - 73-85\%, третьої - 40-57\%. Найменший показник виживаності характерний для четвертої стадії раку, він складає лише 1\%. [3]. Це має спонукати суспільство до запровадження ефективних профілактичних програм, проведення інформаційних компаній щодо особливостей перебігу захворюваності та ведення здорового способу життя. Крім того, ранне виявлення захворювань дозволяє зменшити витрати для проведення лікування, покращити якість життя хворого.

77,4\% жіночого населення України мали у 2015 році I-II стадію нових випадків захворювання на злоякісні новоутворення молочної залози (згідно TNM), III - 13,0\%, IV - 7,5\%, не визначену - 2,1\%. Найвищі показники виявлення раку молочних залоз I-II стадії зафіксовані у Вінницькій (94,6\%), Хмельницькій $(90,7 \%), \quad$ Сумській $\quad(89,6 \%)$, Одеській $\quad(88,1 \%), \quad$ Тернопільській областях. Показники, що є меншими за середньоукраїнські, відмічені у Рівненській $(68,8 \%)$, Житомирській (70,7\%), Дніпропетровській (71,3\%), Запорізькій $(71,4 \%)$, Полтавській та Чернігівській (по $72,2 \%$ ) областях. Показник виявлення третьої стадії захворювання в більшості областей України має незначні коливання від середньоукраїнського. Але в ряді областей він є у 4-5 разів меншим. Такі показники зафіксовані у Вінницькій (2,7\%), Сумській (4,3\%), Волинській (5,6\%), Тернопільській (5,6\%) областях.

Ряд областей України мають показник виявлення IV стадії захворювання, що майже у 1,5 рази перевищує середньоукраїнський. Такими областями є Рівненська (12,7\%), Житомирська (12,5\%), Чернігівська $(12,1 \%)$, Волинська (12,0\%), Черкаська $(11,3 \%)$, Кіровоградська $(11,3 \%)$. У той же час у ряді областей фіксуються низькі показники виявлення IV стадії захворювання на рак молочних залоз. Серед них - Вінницька (2,3\%), Сумська (3,2\%), Хмельницька (3,5\%), Одеська $(4,1)$ та у м. Київ (3,7\%).

У Чернігівській області даний показник склав: I-II стадіï - 72,2 \%, III - 14,5\%, IV - 12,1\%, не визначена - 1,2\%. У межах області відмічені ряд районів у яких зафіксовано 100\% показник нових випадків захворюваності I-II стадії. Це Талалаївський, Менський, Ніжинський райони. Високі показники зафіксовані також у Борзнянському (90\%) та Варвинському $(85,7 \%)$ районах. Але в області серед районів $є$ такі, що мають показник виявлення раку молочних залоз на ранніх стадіях у 1,5 рази меншим, ніж середньообласний. У Варвинському, Ічнянському, Носівському та Сосницькому районах такий показник зафіксовано на рівні 50\%. Показник виявленої третьої стадії захворюваності раку молочних залоз не зафіксований у таких районах як Семенівський, Сосницький, Талалаївський, Менський, Ніжинський, Варвинський. Але більше ніж у два рази він перевищує середньообласний показник у Новгород-Сіверському (42,9\%), Ічнянському (33,3\%), Носівському (30\%) районах. Найбільш складною для лікування є четверта стадія раку молочних залоз. Серед районів області, що має показник який у 4 рази перевищує середньообласний $\epsilon$ Сосницький. Четверта стадія раку молочних залоз у даному районі встановлена у 50\% випадків. У той же час у значній кількості районів (Борзнянському, Коропському, Куликівському, Менському, Ніжинському, Новгород-Сіверському, Ріпкинському, Талалаївському) не було зафіксовано захворювань раку молочних залоз із четвертою стадією. Такий високий показник може свідчити як про зміну ставлення жінок до свого здоров'я, так і про значну профілактичну роботу. Вочевидь, що переоцінка цінностей, зміна пріоритетів відбувалася не так давно. Адже у дослідженнях, проведених у попередні роки, автори, навпаки, відмічають значні рівні занедбаності при виявленні даної патології [7; 9].

Для орієнтовної оцінки стану організації онкодопомоги як допоміжний критерій використовують співвідношення рівня смертності та захворюваності. Пересічно в Україні у 2015 році такий показник склав 49,7. Тобто на кожні 100 зареєстрованих випадків захворювання на злоякісні пухлини припадає майже 50 смертей від даної патології. Показник співвідношення смертності та захворюваності раку молочних залоз для жіночого населення в Україні в цілому складає 42,5.

Найвищі показники зафіксовані у ІваноФранківській $(59,8)$, Чернівецькій $(53,6)$, Рівненській $(53,4)$, Запорізькій $(51,9)$, Полтавській $(48,1)$, Житомирській $(46,7)$ областях. Найменші показники зафіксовані у Одеській $(30,5)$, Миколаївській $(37,2)$, Вінницькій $(37,9)$ областях та м. Києві $(33,7)$. Чернігівська область має показник, що $є$ трохи вищим за середньо український і він складає 43,6\% (Таблиця 1). Аналіз причин високого рівня смертності по відношенню до захворюваності жіночого населення вказує на недоліки в організації онкологічної допомоги в зазначених регіонах і дозволяє вживати певних заходів по іiі удосконаленню.

Враховуючи територіальні відмінності показників захворюваності та смертності жіночого населення від раку молочних залоз, особливості статево-вікової структури жіночого населення було здійснено групування адміністративних районів області за рівнем соціальної напруженості стану здоров'я жіночого населення, що пов'язані 3 раком молочних залоз. Групування було здійснено 3 використанням бального методу. У результаті такого групування райони області були об'єднанні у наступні групи (рис. 4):

$\begin{array}{cccr}- \text { y } & \text { першу } & \text { групу } 3 & \text { найсприятливішим } \\ \text { співвідношенням } & \text { показників } & \text { увійшов }\end{array}$ Ніжинський район;

другу групу із сприятливим співвідношенням склали Ічнянський, Коропський, Корюківський, Ріпкинський, Талалаївський райони;

- третю групу склали райони із недостатньо сприятливим співвідношенням: Бахмацький, Бобровицький, Носівський, Прилуцький, Семенівський, Сосницький, Срібнянський;

несприятливе співвідношення показників відмічене у районах, які були об'єднані у четверту 
Таблиия 1.

Співвідношення показників смертності та захворюваності

\begin{tabular}{|l|l|l|l|}
\hline Адміністративні одиниці & $\begin{array}{l}\text { С п і в в і д н о ш е н н я } \\
\text { показника смертності та } \\
\text { захворюваності у \% }\end{array}$ & Адміністративні одиниці & $\begin{array}{l}\text { С п і в в і д н о ш е н н я } \\
\text { показника смертності та } \\
\text { захворюваності у \% }\end{array}$ \\
\hline Вінницька & 37,9 & Полтавська & 48,1 \\
\hline Волинська & 45,5 & Рівненська & 53,4 \\
\hline Дніпропетровська & 45,5 & Сумська & 40 \\
\hline Житомирська & 46,7 & Тернопільська & 45 \\
\hline Закарпатська & 44,3 & Харківська & 43,7 \\
\hline Запорізька & Херсонська & 41,8 \\
\hline Івано-Франківська & 59,8 & Хмельницька & 44,2 \\
\hline Київська & 42,6 & Черкаська & 40,3 \\
\hline Кіровоградська & 40,3 & Чернівецька & 53,6 \\
\hline Львівська & Чернігівська & 43,6 \\
\hline Миколаївська & 41,1 & м. Київ & 33,7 \\
\hline Одеська & 37,2 & Україна & 42,5 \\
\hline
\end{tabular}

Розраховано на основі даних [3].

Співвідношення показників
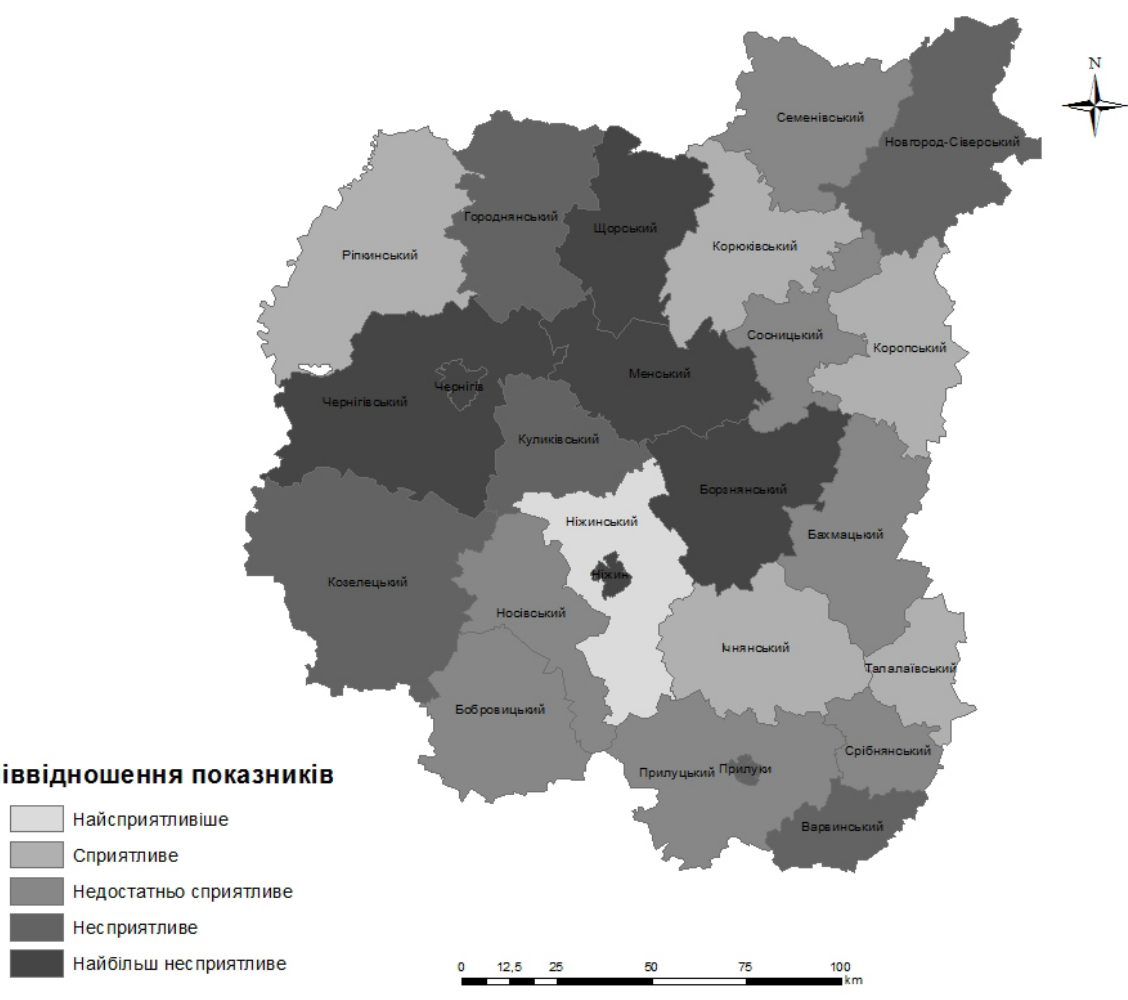

Рис. 4. Групування адміністративних районів Чернігівської області за рівнем соціальної напруженості від раку молочних залоз.

групу: Варвинський, Городнянський, Козелецький, Куликівський, Новгород-Сіверський та м. Прилуки;

- найбільш несприятливе співвідношення мають райони, які увійшли до п’ятої групи. Серед них Борзнянський, Менський, Щорський, Чернігівський райони та м. Ніжин та м. Чернігів.

Висновки. Проведений аналіз захворюваності на рак молочних залоз у межах України та Чернігівської області дозволяє зробити такі висновки:
1. Рак молочної залози займає перше місце серед злоякісних новоутворень усіх локалізацій у структурі захворюваності жіночого населення. Найбільш вразливим для захворюваності $\epsilon$ працездатний вік жінок. У Чернігівській області показник захворюваності є меншим, ніж в Україні.

2. В області, як і в Україні в цілому, спостерігається тенденція до збільшення показника захворюваності на рак молочної залози та стабілізація показника смертності. Однією із причин, що привела 
до стабілізації показника смертності, є виявлення раку молочних залоз у хворих з I-II стадією захворювання, що підкреслює необхідність впровадження скринінгової програми для виявлення раку молочних залоз.

3. У межах Чернігівської області відмічаються територіальні відмінності у стані захворюваності, смертності раку молочної залози. Проведене групування адміністративних районів дало змогу виділити 5 груп районів за рівнем соціальної напруженості показників стану здоров'я жіночого населення, що пов'язані з раком молочних залоз.

4. Моніторинг стану захворюваності населення потрібно проводити і в майбутньому для здійснення об'єктивної оцінки стану здоров'я та визначення шляхів його поліпшення.

\section{References:}

1. Andriiv A.V., Romanchuk V.R., Kryzhanivska A.E. Osoblivostì epìdemìologï ta klìnìko-morfologǐčnì harakteristiki raku moločnih zaloz u hvorih z rìznih ekologìčnih zon İvano-Frankìvs'koï oblastì [Peculiarities of epidemiology and clinical-morphological characteristics of breast cancer in patients from different zones of IvanoFrankivsk region]. Onkologîa [Oncology], 2015, Vol. 17, N. 3, pp. 156-161. (In Ukrainian).

2. Epidemiology and statistics on breast cancer morbidity and mortality in Ukraine. Access mode: www/breast_ cancer.org.

3. Rak v Ukraïnì. Pìdbìrka ŝorìcnih bûletenìv ta ìnših publìkacìj nacìonal'nogo kancer-reêstru Ukraïni [Cancer in Ukraine. Annual selection of newsletters and other publications of the National Cancer Registry of Ukraine]. Access mode: www/ncru.inf.ua. (In Ukrainian).

4. Mezentseva N.I., Batychenko S.P. Suspill'no-geografične doslìdžennâ zahvorûvanostì naselennâ: teoretičnì ta metodičnì osnovi [Human-geographical study of the population morbidity: theoretical and methodical fundamentals]. Ekonomichna ta Sotsialna Geografiya, 2012, Vol. 65, pp. 45-52. (In Ukrainian).

5. Pokazniki stanu zdorov'â naselennâ, diâl'nostì ta resursnogo zabezpečennâ komunal'nih zakladìv ohoroni zdorov'â Černìgìvs'koï oblastì za 2013-2014 roki [Indicators of health status, activities and resources for municipal health care institutions in Chernihiv oblast in 2013-2014] (Ed.: M. V. Bovda). Chernihiv, 2015, 256 p. (In Ukrainian).

6. Rak moločnoï zalozi: simptomi, stadï, likuvannâ [Breast cancer: symptoms, stages, treatment]. Access mode: http://diagnoz.net.ua/onkologiya. (In Ukrainian).

7. Ruden V.V., Moskviak-Lesniak D.Ye. Epìdemìologìčnij analìz zahvorûvanostì žìnok Ukraïni na zloâkìsnì novoutvorennâ moločnoï zalozi u 2000-2008 rokah [Epidemiological regularities of women morbidity on breast malignancy in Ukraine in 2000-2008]. Ukraïna. Zdorov'â naciï [Ukraine. National Health], 2011, N. 2, pp. 57-63. (In Ukrainian).

8. Ruden'V.V., Gutor G.T., Sidorčuk O.M. Pro krizovij stan u zdorov’ï naselennâ kraïni z rinkovimi peretvorennâmi [On the critical state of public health in the state under transition to market]. Ohorona zdorov' $\hat{a}$ Ukraïni [Healthcare in Ukraine], 2006, N 3-4 (22-23), pp.52-59. (In Ukrainian).

9. Rusyn A.V., Zholudeva L.O., Rusyn V.I., Odoshevska O.M., Devinyak O.T. Epìdemìologîâ raku moločnoï zalozi v Zakarpats'kìj oblastì [Oncoepidemiology of Breast Cancer in Transcarpathian Region]. Ukrainian Journal of Surgery, 2012, N. 4 (19), pp. 110-113. (In Ukrainian). 